\title{
Technology in the Sialkot Gloves Manufacturing Sector
}

\section{Saba Firdousi ${ }^{*}$}

\begin{abstract}
This paper uses a unique sample of sports glove manufacturers from Sialkot to develop an index of technological sophistication. The data shows that total factor productivity (TFP) and total revenue productivity (TRP) cluster around their mean levels. The medium-tech and high-tech firms seem to have a higher TFP and LP than the low-tech firms. Another interesting result is that, across firms, the level of retained earnings has a negative impact on TFP and TRP.
\end{abstract}

Keywords: Technology, manufacturing, gloves, Sialkot, Pakistan.

JEL classification: L67, O14.

\section{Introduction}

There is a rich body of literature that provides both empirical and theoretical evidence that firms' investment in technology is a key factor in rapid industrial growth (see Amsden \& Chu, 2003; Lall \& Urata, 2003; Mathews \& Cho, 2007). The bulk of the empirical evidence finds that most firms in developing economies fail to invest in technology, which could not only fuel growth, but also lead to export diversification. In this paper, we focus on Pakistani-made sports gloves - a rapidly growing export sector.

There are several reasons for focusing on this sector: First, sports glove exports are growing rapidly and Pakistan is a major player in this market. Its exports of sports gloves increased by $\$ 25$ million in 2013/14, while exports of other sports goods fell during this period. Second, the glove production process is relatively simple, which allows us to map it and to determine the technologies used in each step. Finally, given the small number of glove manufacturers in Sialkot, our sample of firms is fairly representative of the population.

In comparison to the literature, we focus on the level of technology adopted at each stage of the production process. We also attempt to measure the impact of technology adoption based on how technology is related to

${ }^{*}$ Lahore School of Economics. 
firm-level measures of productivity. Our main objective is to analyze whether productivity, firm size, management practices, financial constraints, research and development (R\&D) and export destinations affect technology adoption at the firm level.

Figure 1 shows where Pakistani-made sports gloves are primarily exported. High-to-medium-quality gloves are exported largely to North America and Europe, while low-quality gloves are exported to Australia and Asian markets.

\section{Figure 1: Export destinations for gloves, by quality of good}

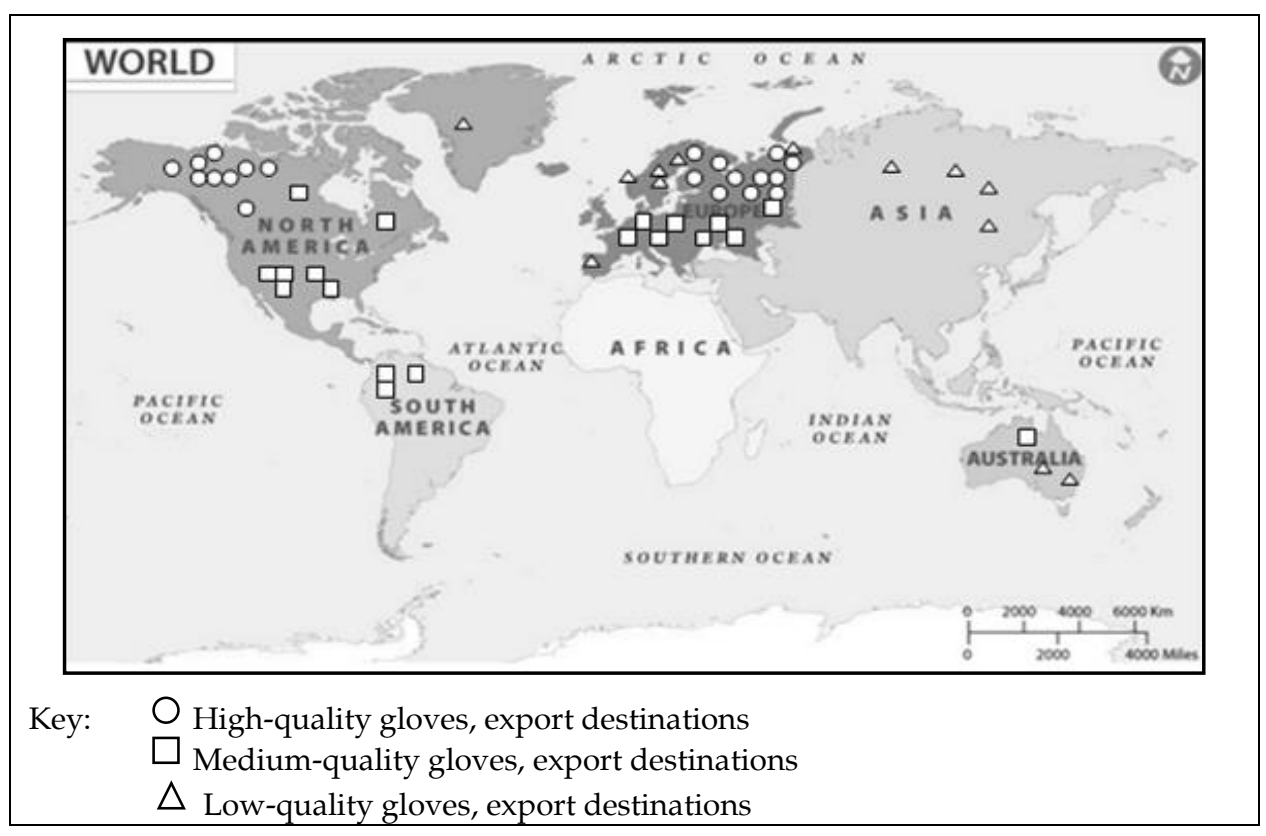

Source: Authors' calculations.

\section{Literature Review}

During the second half of the 20th century, a number of developing countries, especially in East Asia, experienced rapid growth in productivity and economic performance. This was tied not only to the changing structure of international trade, but also to new factors being introduced into global competition. Porter (1990) highlights some of these factors, which include foreign direct investment, increased product variety, communication and transport networks and the adoption of new technologies. Lall (2001) also focuses on the connection between export performance and firms' adoption of technology. 
Many of the empirical studies looking at the link between technology and export performance find mixed results. Cotsomitis, DeBresson and Kwan (1991) and Kumar (2002) find only weak evidence of this link. More recent work has found that technology adoption - measured by R\&D expenditure - has a positive impact on export performance (see Kumar \& Siddharthan, 1994; Basile, 2001). Lal (2002) finds that the adoption of ebusiness technologies has had a significant impact on the export performance of small and medium industries in India.

Generally, the theoretical and empirical evidence implies that the adoption of technology plays a role in the performance of manufacturing firms. In this paper, we hypothesize that firm-level technology adoption can explain differences across exporting firms in the Sialkot sports glove industry.

\section{Study Sample}

The study is based on a field survey of 20 registered small, medium and large sports glove manufacturers in Sialkot, Pakistan. There are about 500 registered glove firms in Sialkot, but we have restricted our sample to those producing sports gloves. According to firm-level information from the Sialkot Chamber of Commerce, there are approximately 35 registered sports glove firms in Sialkot, of which we randomly selected 20 firms to survey. The questionnaire asked respondents about firm size, R\&D expenditures, export destinations, production processes and machinery, technology adoption and the cost and the quality of gloves produced. In addition to the survey, we also mapped each firm's production process.

\section{Mapping the Gloves Production Process}

The production of sports gloves is relatively simple. After the raw materials are procured and checked for quality, the leather or faux leather (rexine) is cut into pieces using a pair of scissors or a hydraulic cutting machine. Next, the designs or emblems are painted onto the cut pieces, which are then stitched together. Finally, they are checked for quality and hand-finished before being packed. Figure 2 shows the production steps. 
Figure 2: Glove production process flow

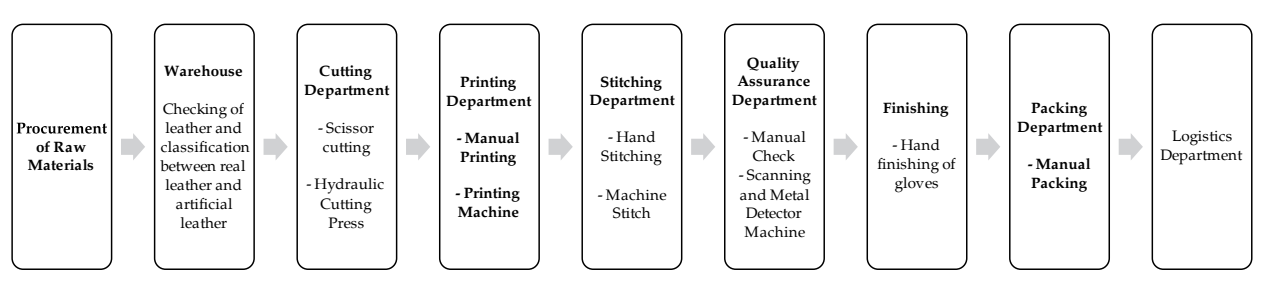

What makes the production process interesting is that all firms tend to rely on manual labor to procure and check the raw materials, and to finish and pack the final product. However, they vary in terms of the technologies used in the cutting, printing and stitching. While some firms carry out the cutting manually (using pairs of scissors), others use hydraulic cutting presses. Similarly, some firms print the emblems on the rexine by hand while others use automated printing machines. Finally, some firms use manual labor to stitch the gloves while others use sewing machines.

\section{Measuring Technology in the Production Process}

A key issue in this paper is how the level of technology varies across firms. In order to determine technology levels, we create a new firm-level technology ranking based on the sophistication of the technology used at each step of the production process. A firm is ranked 'low-tech' if it uses machinery solely at the stitching stage. A 'medium-tech' firm uses machinery in the cutting and stitching of gloves. A firm is ranked 'high-tech' if it uses machinery in the cutting, stitching and printing of gloves. Figure 3 shows that firms have moved up the technology ladder from low-tech to medium-tech, but not from medium-tech to high-tech.

\section{Figure 3: Technology levels of glove manufacturers}

2013

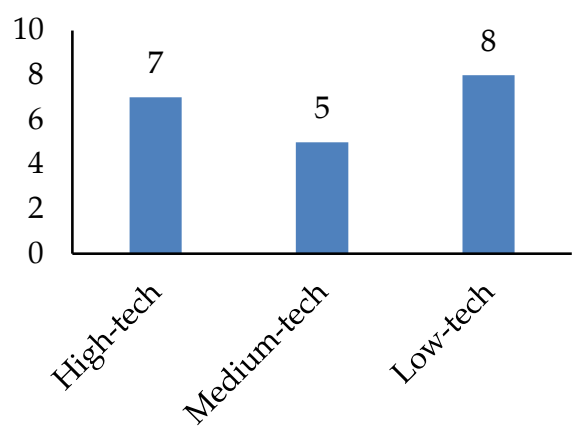

2015

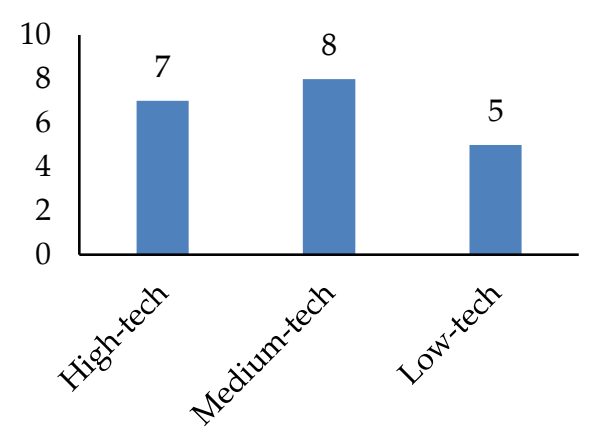


Tables 1 and 2 show that medium-tech production and revenue is about four times that of small-tech production and revenue. Similarly, largetech production and revenue is about four times that of medium-tech production and revenue. Interestingly, there is less difference between lowtech and medium-tech firms in terms of the cost of capital, but a substantial difference in the cost of capital between medium-tech and high-tech firms.

Table 1: Differences between firms, by technology level

\begin{tabular}{lrrrrrr}
\hline & Production & Revenue & Cost & Profit & Markup & Cap. cost \\
\hline Technology & $\mathbf{1}$ & $\mathbf{2}$ & $\mathbf{3}$ & $\mathbf{4}$ & $\mathbf{5}$ & \multicolumn{1}{c}{$\mathbf{6}$} \\
\hline High & $3,384,000$ & $2,694,735,000$ & $1,555,355,379$ & $1,139,379,621$ & 73.82 & $31,735,779$ \\
Medium & 768,000 & $925,560,000$ & $517,358,434$ & $408,201,566$ & 66.77 & 794,262 \\
Low & 140,571 & $23,786,0571$ & $157,553,896$ & $80,306,675$ & 55.00 & 679,834 \\
\hline
\end{tabular}

Note: 1 = average annual production: total number of gloves (quality = high, medium and low) produced by the firm on average in a year.

2 = average total revenue: total revenue generated by selling gloves (quality $=$ high, medium and low) on average at their respective prices in a year.

3 = average total cost: the sum of the cost of materials, labor, energy and capital for the firm in a year.

$4=$ average annual profit: the difference between total revenue and total cost, including the firm's overheads, in a year.

5 = average markup: annual profit divided by total cost.

6 average current year cost of capital: yearly cost of machinery used in the firm's production process, net of depreciation.

Source: Authors' calculations.

Table 2: Percentage differences between firms, by technology level

\begin{tabular}{lcccccc}
\hline & \multicolumn{7}{c}{ Difference in } \\
\hline \% Difference & Production & Revenue & Cost & Profit & Markup & Cap. cost \\
from & $\mathbf{1}$ & $\mathbf{2}$ & $\mathbf{3}$ & $\mathbf{4}$ & $\mathbf{5}$ & $\mathbf{6}$ \\
\hline Low to medium & 446.34 & 289.12 & 228.37 & 408.30 & 20.84 & 16.83 \\
Medium to high & 340.63 & 191.15 & 200.63 & 179.12 & 10.56 & $3,895.63$ \\
Low to high & $2,307.00$ & $1,033.00$ & 887.00 & $1,319.00$ & 34.00 & $4,568.00$ \\
\hline
\end{tabular}

Note: 1 = average annual production: total number of gloves (quality = high, medium and low) produced by the firm on average in a year.

2 = average total revenue: total revenue generated by selling gloves (quality = high, medium and low) on average at their respective prices in a year.

3 = average total cost: the sum of the cost of materials, labor, energy and capital for the firm in a year.

$4=$ average annual profit: the difference between total revenue and total cost, including the firm's overheads, in a year.

5 = average markup: annual profit divided by total cost.

6 average current year cost of capital: yearly cost of machinery used in the firm's production process, net of depreciation.

Source: Authors' calculations. 


\section{Measuring Productivity}

To determine the link between technology and productivity, we look at three different measures of firm-level productivity: (i) total factor productivity (TFP), (ii) total revenue productivity (TRP) and (iii) labor productivity (LP).

Using a Cobb-Douglas production function with four factors of production (capital, labor, energy and intermediate goods), we estimate TFP and TRP. The Cobb-Douglas specification used in the estimation is:

$$
Y_{i j}=A_{i j} K_{i j}^{\alpha_{i j}} L_{i j}^{\beta_{i j}} M_{i j}^{\gamma_{i j}} E_{i j}^{\mu_{i j}}
$$

where $Y_{i j}$ is output, $K_{i j}$ is the replacement value of machinery for a given year, $L_{i j}$ is the labor cost, $M_{i j}$ is the cost of materials and $E_{i j}$ is the energy cost. Additionally,

$$
\begin{aligned}
\alpha_{i j} & =\frac{\text { Capital cost }_{i j}}{\text { Total } \operatorname{cost}_{i j}} \\
\beta_{i j} & =\frac{\text { Labor cost }_{i j}}{\text { Total cost }_{i j}} \\
\lambda_{i j} & =\frac{\text { Materials cost }_{i j}}{\text { Total cost }_{i j}} \\
\mu_{i j} & =\frac{\text { Energy cost }_{i j}}{\text { Total cost }_{i j}}
\end{aligned}
$$

Productivity is then measured by:

$$
A_{i j}=Y_{i j} / K_{i j}^{\alpha_{i j}} L_{i j}^{\beta_{i j}} M_{i j}^{\gamma_{i j}} E_{i j}^{\mu_{i j}}
$$

where $Y_{i j}$ is measured in terms of total output to calculate TFP and $Y_{i j}$ is measured in terms of total sales to calculate TRP.

Thus, TFP is estimated as the nonparametric residual term of the production function, where output is measured in terms of the number of gloves sold and the output elasticity of each input factor is calculated as the cost share of that input in total cost. Firm sales are measured by the number of pairs of gloves sold (including the value of all high-, medium- and low- 
quality gloves). TRP is estimated using firm sales in rupee terms (price $x$ quantity). The capital cost is calculated using data for all types of machinery used in the production process, the years in which they were operational, the expected life of the machines and their depreciation. Labor cost is the sum of the total compensation given to workers directly involved in production. Intermediate goods are determined as the sum of the per unit cost of raw materials and intermediate materials, multiplied by the number of gloves produced.

Next, we calculate LP as total output divided by the number of workers:

$$
L P=Y_{i j} / \text { Number of workers }
$$

Table 3 gives descriptive statistics for the firms' output and cost of materials, labor, capital and energy according to their level of technology adoption. On average, the output produced by high-tech firms is significantly larger than that of medium-tech and low-tech firms in both 2015 and 2013. Moreover, material, labor, capital and energy costs increase for all types of firms over the span of two years. As expected, high-tech firms have higher total costs than medium-to-low-tech firms.

\section{Table 3: Descriptive statistics: inputs and outputs, by level of technology}

\begin{tabular}{lrrrrr}
\hline Technology level & Output & $\begin{array}{c}\text { Materials } \\
\text { cost }\end{array}$ & Labor cost & $\begin{array}{c}\text { Capital } \\
\text { cost }\end{array}$ & $\begin{array}{c}\text { Energy } \\
\text { cost }\end{array}$ \\
\hline Average: high-tech 15 & $3,384,000$ & $1,276,767,450$ & $193,999,650$ & $31,735,779$ & $52,852,500$ \\
SD: high-tech 15 & $3,829,523$ & $1,386,218,298$ & $227,422,172$ & $56,640,351$ & $55,501,760$ \\
Average: medium-tech 15 & 768,000 & $436,902,600$ & $66,573,000$ & 679,834 & $13,203,000$ \\
SD: medium-tech 15 & 650,938 & $358,268,042$ & $41,065,338$ & 545,816 & $8,351,676$ \\
Average: low-tech 15 & 140,571 & $123,373,371$ & $27,307,063$ & 794,262 & $6,079,200$ \\
SD: low-tech 15 & 109,666 & $124,557,440$ & $32,528,779$ & 678,600 & $8,027,153$ \\
Average: high-tech 13 & $3,677,143$ & $1,039,784,714$ & $183,462,321$ & $39,780,515$ & $49,029,857$ \\
SD: high-tech 13 & $3,663,230$ & $1,175,298,253$ & $187,543,863$ & $65,630,377$ & $42,219,687$ \\
Average: medium-tech 13 & 688,800 & $335,551,800$ & $56,563,920$ & 747,816 & $10,202,400$ \\
SD: medium-tech 13 & 547,537 & $242,763,836$ & $35,549,384$ & 600,398 & $5,820,435$ \\
Average: low-tech 13 & 138,000 & $106,778,700$ & $24,102,750$ & 865,883 & $5,243,250$ \\
SD: low-tech 13 & 107,283 & $108,801,517$ & $31,677,437$ & 691,440 & $7,608,396$ \\
\hline
\end{tabular}

Note: $\mathrm{SD}=$ standard deviation.

Source: Authors' calculations. 
Figure 4 shows the average trend in the firms' TFP. For both years, 2013 and 2015, a significant number of firms are clustered around the mean TFP and only one firm experiences above-average productivity. As Figure 5 shows, in 2015 there are 15 firms clustered around the average TRP, with one firm experiencing higher-than-average TRP. In 2013, more firms are clustered around the average TFP, while only two experience below-average TFP. Figure 6 shows the average LP trend. In 2015, the average LP of the firms improves in comparison to 2013.

In general, Figures 4, 5 and 6 show TFP and TRP clustering around their mean productivity levels. For 2015, the lower tail of the distribution of TFP becomes thicker, which indicates a larger number of low-productivity firms. This is reinforced by the LP distribution, which has a fat lower tail, implying that firms cluster around a lower LP. Figure 7 shows productivity by technology level: medium-tech and high-tech firms seem to have significantly higher productivity than low-tech firms.

\section{Figure 4: TFP of glove manufacturers}
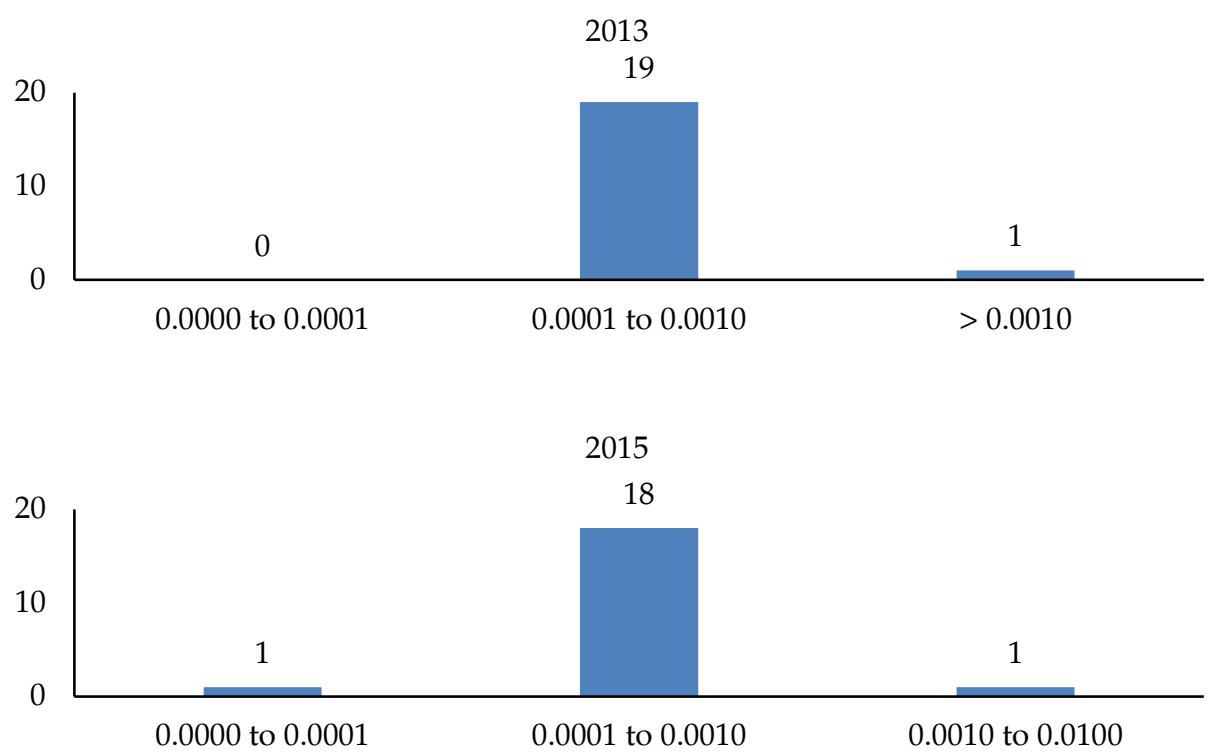
Figure 5: TRP of glove manufacturers
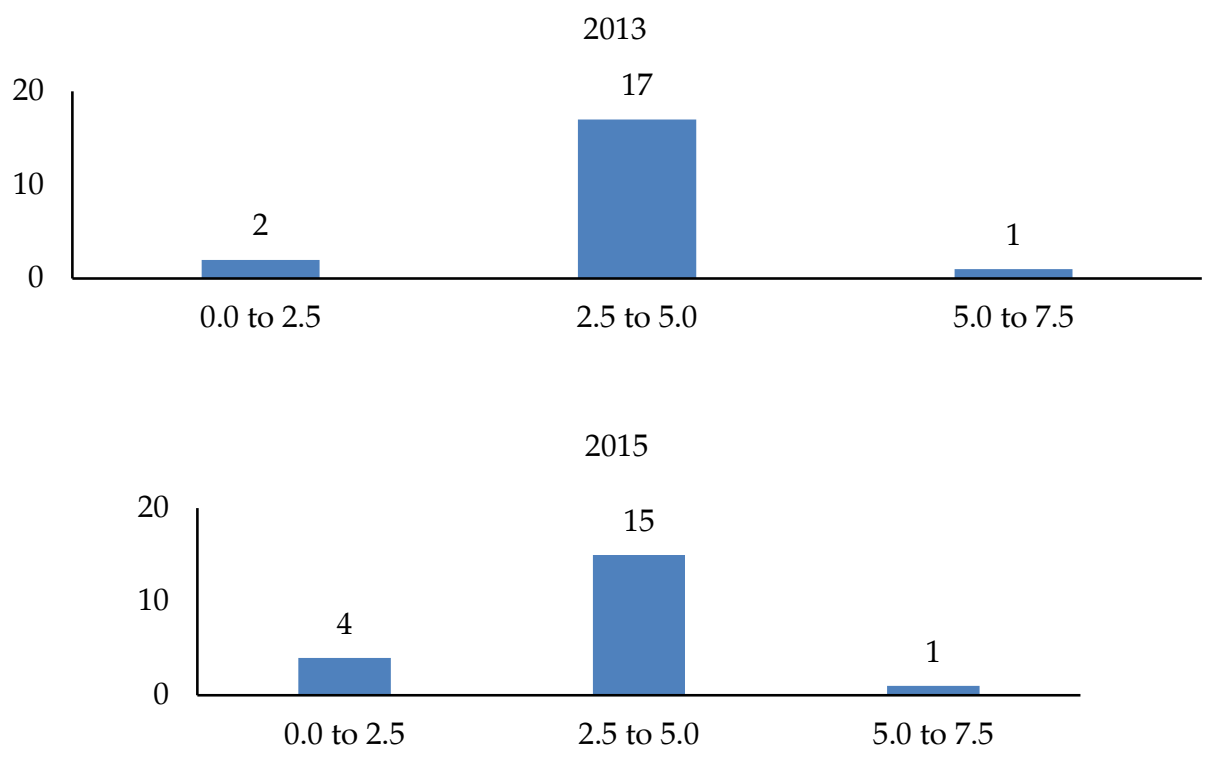

Figure 6: LP of glove manufacturers

2013

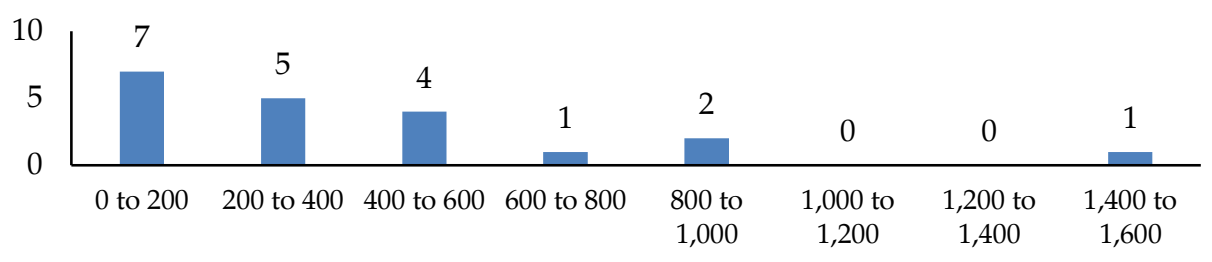

2015

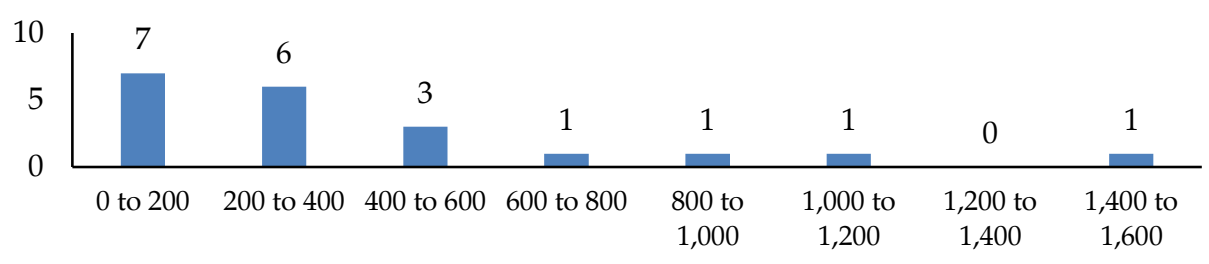


Figure 7: TFP, TRP and LP, by level of technology

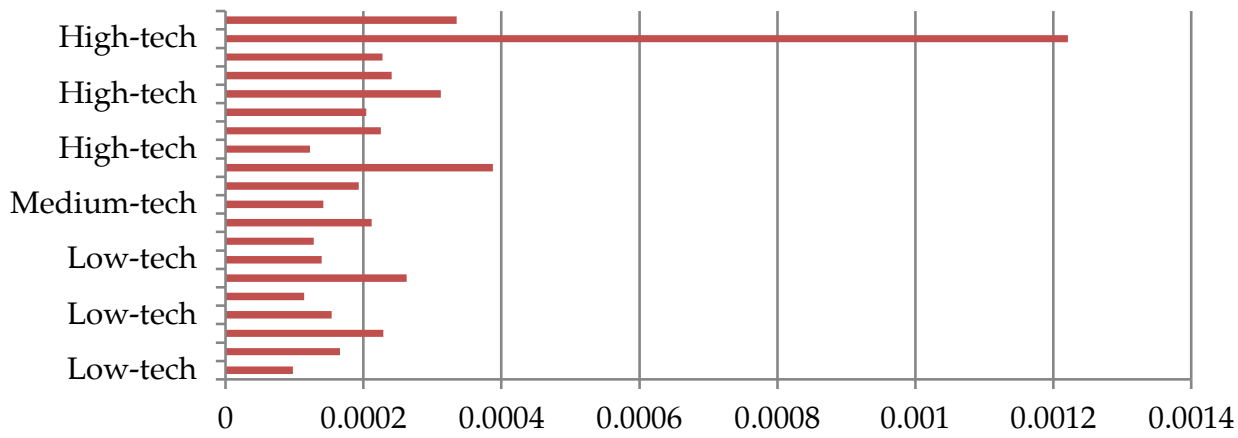

- Total Factor Productivity

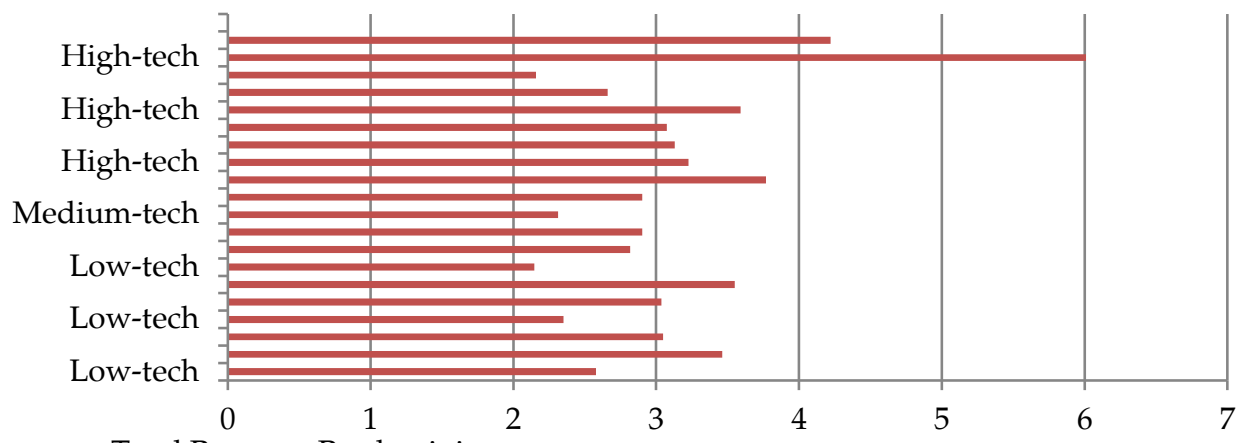

- Total Revenue Productivity

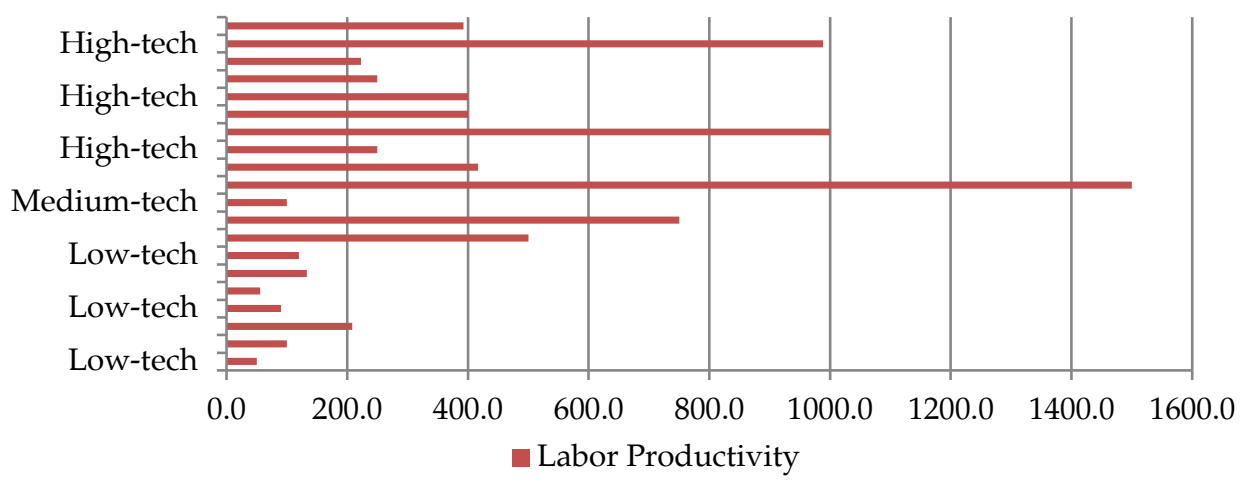

\section{Estimating Technology Adoption and the Relationship between Productivity and Technology}

In order to analyze the correlates of technology adoption, we estimate an ordered logit model that tests the impact of factors such as firm size, age, production, ownership, finance, owner's education, profitability, 
R\&D spending and export destinations on technology adoption. The model is written as:

Technology adoption $=\alpha_{0}+\alpha_{1}$ age of firm fir $_{i}+$

$\alpha_{2}$ firm profitability $_{i}+\alpha_{3} R \& D_{i}+\alpha_{4}$ firm size $_{i}+$

$\alpha_{5}$ owner's education $_{i}+e_{i}$

To see how technology adoption and firm-level characteristics affect TFP, TRP and LP, we estimate:

$$
\text { TFP }=\alpha_{0}+\alpha_{1} \text { age of } \text { firm }_{i}+\alpha_{2} \text { retained earning } s_{i}+
$$

$\alpha_{3}$ firm profitability $_{i}+\alpha_{4}$ technology adoption $_{i}+\alpha_{5}$ firm size $_{i}+$ $\alpha_{6}$ production capacity $_{i}+\alpha_{7} R \& D_{i}+\alpha_{8}$ owner's education $_{i}+$ $\alpha_{9}$ education of owner's child ${ }_{i}+e_{i}$

$$
T R P=\alpha_{0}+\alpha_{1} \text { age of } \text { firm }_{i}+\alpha_{2} \text { retained earnings } s_{i}+
$$

$\alpha_{3}$ firm profitability $_{i}+\alpha_{4}$ technology adoption $_{i}+\alpha_{5}$ firm $_{\text {size }}+$ $\alpha_{6}$ production capacity $_{i}+\alpha_{7} R \& D_{i}+\alpha_{8}$ owner's education $_{i}+$ $\alpha_{9}$ education of owner's child $i+e_{i}$

$$
L P=\alpha_{0}+\alpha_{1} \text { age of } \text { firm }_{i}+\alpha_{2} \text { retained earning } s_{i}+
$$

$\alpha_{3}$ firm profitability $_{i}+\alpha_{4}$ technology adoption $_{i}+\alpha_{5}$ firm size $_{i}+$ $\alpha_{6}$ production capacity $_{i}+\alpha_{7} R \& D_{i}+\alpha_{8}$ owner's education $_{i}+$ $\alpha_{9}$ education of owner's child $i+e_{i}$

\section{Empirical Results}

The empirical results in Table 4 show that the age of a firm is negatively related to technology adoption, which implies that older firms innovate less than younger (newer) firms. They are more likely to continue with the conventional production methods in which they have gained expertise over time. The idea is that, while adopting new machines and advanced process technologies can increase firms' output, the cost of switching from old to new technologies is perceived to be too high.

Our interviews with the firms' main decision makers reveal that owners think most of their workforce is relatively unskilled and adopting new technologies would require both a skilled workforce and technical training, which most firms lack. These findings are consistent with the literature: many new firms start as large enterprises and are more likely to adopt advanced technologies in order to obtain a greater market share (see Mahmood, Din \& Ghani, 2009; Faria et al., 2002; Bortamuly \& Goswami, 2015). 
The empirical results also show that firm profitability has a positive relationship with technology adoption. This implies that firms with higher technology have an edge over firms with low technology in terms of higher profit margins. This is probably because firms with higher profit margins invest more in the acquisition of advanced technology. This is in line with the empirical literature, which finds that firms with high profit margins tend to adopt the latest machines to develop and maintain a competitive advantage in their markets (Stoneman \& Kwon, 1996; Suri, 2011).

Tables 7, 8 and 9 show that the age of a firm positively affects productivity across specifications. This implies that older firms tend to be more productive than younger firms. Moreover, retained earnings and firm profitability negatively affect productivity across specifications.

This interesting (and counterintuitive) result has several possible reasons. First, the investment objectives of firm insiders (managers, owners, founders and family) are unclear in that, if income streams are linked to the wealth of the firm they manage, they are less likely to favor a high-risk strategy, leading to lower productivity (Ishengoma, 2004). Second, keeping in mind agency theory, the discrete shareholding of large enterprises is related to information asymmetries. This results in poor control by the management, which is in direct conflict with stakeholders' interests. Thus, managers may aim to maximize their respective utilities at the expense of decreased productivity (see Hill \& Snell, 1989). Third, as a firm grows older, its productivity stagnates relative to new firms (Huergo \& Jaumandreu, 2004). 
Table 4: Factors affecting technology adoption

\begin{tabular}{llc}
\hline Variable & OLS estimates & Ordered logit estimates \\
\hline Age of firm & $-0.128^{* *}$ & -0.427 \\
Retained earnings & $(0.0483)$ & $(0.312)$ \\
& $16.23^{* * *}$ & $59.09^{*}$ \\
Firm profitability & $(5.038)$ & $(33.20)$ \\
& $1.05 \mathrm{e}-09^{* * *}$ & $7.35 \mathrm{e}-09^{* *}$ \\
R\&D & $(3.18 \mathrm{e}-10)$ & $(3.35 \mathrm{e}-09)$ \\
& $-3.44 \mathrm{e}-09^{*}$ & $1.36 \mathrm{e}-07$ \\
Firm size & $(1.70 \mathrm{e}-09)$ & $(4.62 \mathrm{e}-07)$ \\
& -0.150 & -1.569 \\
Owner's education & $(0.231)$ & $(1.596)$ \\
Constant cut1 & -0.0940 & -0.599 \\
& $(0.0766)$ & $(0.477)$ \\
Constant cut2 & & -3.133 \\
Constant & & $(5.753)$ \\
Observations & & 0.283 \\
R-squared & 1.636 & $(6.176)$ \\
\hline
\end{tabular}

Note: The dependent variable is technology adoption, a dummy variable where $1=$ low-tech (firm uses machinery in stitching only), 2 = medium-tech (firm uses machinery in cutting and stitching) and 3 = high-tech (firm uses machinery in cutting, stitching and printing).

The independent variables are:

Age of firm: the number of years since the firm started manufacturing gloves.

Retained earnings: the percentage of the firm's retained earnings in 2015.

Firm profitability: the firm's annual profits.

$R \mathcal{E} D$ : the yearly cost incurred by the firm on R\&D.

Firm size: a dummy variable where 1 = small (0-50 employees), 2 = medium (50-250 employees) and $3=$ large ( $>250$ employees).

Owner's education: a dummy variable where 16 = postgraduate, 14 = undergraduate, $12=$ intermediate, $10=$ matric $/ O$ levels, $8=$ middle school, $0=$ less than middle school.

Standard errors in parentheses. ${ }^{* * *} \mathrm{p}<0.01,{ }^{* *} \mathrm{p}<0.05,{ }^{*} \mathrm{p}<0.1$.

Source: Authors' calculations. 
Table 5: Factors affecting TFP

\begin{tabular}{ll}
\hline Variable & \multicolumn{1}{c}{ TFP } \\
\hline Age of firm & $1.84 \mathrm{e}-05^{* *}$ \\
& $(7.67 \mathrm{e}-06)$ \\
Retained earnings & $-0.00175^{*}$ \\
& $(0.000802)$ \\
Firm profitability & $-2.84 \mathrm{e}-13^{* *}$ \\
& $(1.22 \mathrm{e}-13)$ \\
Technology adoption & $7.52 \mathrm{e}-05^{* *}$ \\
& $(2.95 \mathrm{e}-05)$ \\
Firm size & $3.79 \mathrm{e}-06$ \\
& $(2.59 \mathrm{e}-05)$ \\
Production capacity & $8.39 \mathrm{e}-11^{*}$ \\
& $(4.06 \mathrm{e}-11)$ \\
R\&D & $8.16 \mathrm{e}-13^{* * *}$ \\
& $(2.30 \mathrm{e}-13)$ \\
Owner's education & $1.53 \mathrm{e}-05$ \\
& $(8.75 \mathrm{e}-06)$ \\
Education of owner's child & $-3.24 \mathrm{e}-05^{* *}$ \\
Constant & $(1.19 \mathrm{e}-05)$ \\
& $0.000364^{* *}$ \\
Observations & $(0.000144)$ \\
R-squared & 20 \\
\hline
\end{tabular}

Note: The dependent variable is TFP in 2015.

The independent variables are:

Age of firm: the number of years since the firm started manufacturing gloves.

Retained earnings: the percentage of the firm's retained earnings in 2015.

Firm profitability: the firm's annual profits.

Technology adoption: a dummy variable where $1=$ low-tech (firm uses machinery in stitching only), 2 = medium-tech (firm uses machinery in cutting and stitching) and $3=$ high-tech (firm uses machinery in cutting, stitching and printing).

Firm size: a dummy variable where 1 = small (0-50 employees), 2 = medium (50-250 employees) and $3=$ large ( $>250$ employees).

Production capacity: the number of gloves produced on average by firms in 2015.

Owner's education: a dummy variable where 16 = postgraduate, $14=$ undergraduate, $12=$ intermediate, $10=$ matric $/ O$ levels, $8=$ middle school, $0=$ less than middle school.

Education of owner's child: a dummy variable where $16=$ postgraduate, $14=$ undergraduate, 12 intermediate and $10=$ in school.

$R \mathcal{E} D$ : the yearly cost incurred by the firm on R\&D.

Standard errors in parentheses. ${ }^{* * *} \mathrm{p}<0.01,{ }^{* *} \mathrm{p}<0.05,{ }^{*} \mathrm{p}<0.1$.

Source: Authors' calculations. 
Table 6: Factors affecting TRP

\begin{tabular}{ll}
\hline Variable & \multicolumn{1}{c}{ TRP } \\
\hline Age of firm & $0.0883^{* *}$ \\
& $(0.0387)$ \\
Retained earnings & $-8.782^{*}$ \\
& $(4.045)$ \\
Firm profitability & $-7.81 \mathrm{e}-12$ \\
& $(6.17 \mathrm{e}-10)$ \\
Technology adoption & $0.325^{*}$ \\
& $(0.149)$ \\
Firm size & -0.0231 \\
& $(0.130)$ \\
Production capacity & $-1.71 \mathrm{e}-07$ \\
& $(2.05 \mathrm{e}-07)$ \\
R\&D & $4.41 \mathrm{e}-09^{* * *}$ \\
& $(1.16 \mathrm{e}-09)$ \\
Owner's education & $0.145^{* * *}$ \\
& $(0.0441)$ \\
Education of owner's child & $-0.125^{*}$ \\
& $(0.0598)$ \\
Constant & $2.743^{* * *}$ \\
& $(0.728)$ \\
Observations & 20 \\
R-squared & 0.871 \\
\hline
\end{tabular}

Note: The dependent variable is TRP in 2015.

The independent variables are:

Age of firm: the number of years since the firm started manufacturing gloves.

Retained earnings: the percentage of the firm's retained earnings in 2015.

Firm profitability: the firm's annual profits.

Technology adoption: a dummy variable where $1=$ low-tech (firm uses machinery in stitching only), 2 = medium-tech (firm uses machinery in cutting and stitching) and $3=$ high-tech (firm uses machinery in cutting, stitching and printing).

Firm size: a dummy variable where $1=$ small (0-50 employees), 2 = medium (50-250 employees) and $3=$ large ( $>250$ employees).

Production capacity: the number of gloves produced on average by firms in 2015.

Owner's education: a dummy variable where 16 = postgraduate, $14=$ undergraduate, $12=$ intermediate, $10=$ matric $/ O$ levels, $8=$ middle school, $0=$ less than middle school.

Education of owner's child: a dummy variable where $16=$ postgraduate, $14=$ undergraduate, 12 intermediate and $10=$ in school.

$R \mathcal{E} D$ : the yearly cost incurred by the firm on R\&D.

Standard errors in parentheses. ${ }^{* *} \mathrm{p}<0.01,{ }^{* *} \mathrm{p}<0.05,{ }^{*} \mathrm{p}<0.1$.

Source: Authors' calculations. 
Table 7: Factors affecting LP

\begin{tabular}{ll}
\hline Variable & LP \\
\hline Age of firm & 22.98 \\
& $(30.76)$ \\
Retained earnings & $-3,531$ \\
& $(3,216)$ \\
Firm profitability & $8.44 \mathrm{e}-07$ \\
& $(4.90 \mathrm{e}-07)$ \\
Technology adoption & $257.5^{*}$ \\
& $(118.5)$ \\
Firm size & -53.49 \\
& $(103.7)$ \\
Production capacity & $-0.000326^{*}$ \\
& $(0.000163)$ \\
R\&D & $2.35 \mathrm{e}-06^{* *}$ \\
& $(9.21 \mathrm{e}-07)$ \\
Owner's education & 43.73 \\
& $(35.10)$ \\
Education of owner's child & 9.971 \\
& $(47.58)$ \\
Constant & -321.4 \\
& $(578.9)$ \\
Observations & 20 \\
R-squared & 0.764 \\
\hline
\end{tabular}

Note: The dependent variable is $L P$ in 2015.

The independent variables are:

Age of firm: the number of years since the firm started manufacturing gloves.

Retained earnings: the percentage of the firm's retained earnings in 2015.

Firm profitability: the firm's annual profits.

Technology adoption: a dummy variable where $1=$ low-tech (firm uses machinery in stitching only), 2 = medium-tech (firm uses machinery in cutting and stitching) and $3=$ high-tech (firm uses machinery in cutting, stitching and printing).

Firm size: a dummy variable where 1 = small (0-50 employees), 2 = medium (50-250 employees) and $3=$ large ( $>250$ employees).

Production capacity: the number of gloves produced on average by firms in 2015.

Owner's education: a dummy variable where 16 = postgraduate, $14=$ undergraduate, $12=$ intermediate, $10=$ matric $/ O$ levels, $8=$ middle school, $0=$ less than middle school.

Education of owner's child: a dummy variable where $16=$ postgraduate, $14=$ undergraduate, 12 = intermediate and $10=$ in school.

$R \mathcal{E} D$ : the yearly cost incurred by the firm on R\&D.

Standard errors in parentheses. ${ }^{* * *} \mathrm{p}<0.01,{ }^{* *} \mathrm{p}<0.05,{ }^{*} \mathrm{p}<0.1$.

Source: Authors' calculations. 
Most importantly, our results show that technology adoption has a positive impact on firm-level productivity across specifications. This result is supported by Mayer (2001), who develops a theoretical link between technology adoption and productivity. Hasan (2002) looks at this relationship for Indian manufacturing firms and finds that embodied technology inputs result in significant productivity growth rates. Bartelsman, Van Leeuwen and Nieuwenhuijsen (1998) find a significant relationship between the adoption of advanced technologies and productivity growth levels for firms in the Netherlands.

Finally, our results indicate that production capacity and R\&D have a positive effect on productivity across specifications, unlike the simple OLS and ordered logit results. Lichtenberg and Siegel (1991) obtain similar results for a sample of US firms, as do Hall and Mairesse (1995).

\section{Conclusion}

This paper uses a unique sample of sports glove manufacturers from Sialkot to develop an index of technological sophistication by mapping the various technologies used at each step of the glove manufacturing process. We estimate the TFP, TRP and LP of each firm to see if productivity is related to technological sophistication. A casual inspection of the data shows that TFP and TRP cluster around their mean levels. The thick lower tail of the TRP distribution implies that the sample includes a large number of lowproductivity firms.

This result is reinforced by the LP distribution, which has a fat lower tail. This means that firms cluster around a lower LP. The medium-tech and high-tech firms seem to have a higher TFP and LP than the low-tech firms. Moreover, in our empirical analysis, we look at the correlates of technology adoption and productivity in the sample. A key result is that higher levels of technology have a positive and significant impact on productivity.

Another interesting result is that, across firms, the level of retained earnings has a negative impact on TFP and TRP. This may reflect the fact that firms that retain higher earnings are not investing in R\&D or technology. This could indicate that, in an uncertain environment such as Pakistan, firms are more concerned about present earnings than making investments that might pay off in the future. 


\section{References}

Amsden, A. H., \& Chu, W.-W. (2003). Beyond late development: Taiwan's upgrading policies. Cambridge, MA; MIT Press.

Bartelsman, E., Van Leeuwen, G., \& Nieuwenhuijsen, H. (1998). Adoption of advanced manufacturing technology and firm performance in The Netherlands. Economics of Innovation and New Technology, 6(4), 291-312.

Basile, R. (2001). Export behavior of Italian manufacturing firms over the nineties: The role of innovation. Research Policy, 30(8), 1185-1201.

Bortamuly, A. B., \& Goswami, K. (2015). Determinants of the adoption of modern technology in the handloom industry in Assam. Technological Forecasting and Social Change, 90, 400-409.

Cotsomitis, J., DeBresson, C., \& Kwan, A. (1991). A re-examination of the technology gap theory of trade: Some evidence from time series data for OECD countries. Review of World Economics, 127(4), 792799.

David, P. A. (1969). A contribution to the theory of diffusion (Memorandum No. 71). Stanford, CA: Stanford Center for Research in Economic Growth.

David, P. A. (1975). Technical choice innovation and economic growth: Essays on American and British experience in the nineteenth century. London: Cambridge University Press.

Davies, S. (1979). The diffusion of process innovations. Cambridge: Cambridge University Press.

Faria, A., Fenn, P., \& Bruce, A. (2002). Determinants of adoption of flexible production technologies: Evidence from Portuguese manufacturing industry. Economics of Innovation and New Technology, 11(6), 569-580.

Hall, B. H., \& Mairesse, J. (1995). Exploring the relationship between R\&D and productivity in French manufacturing firms. Journal of Econometrics, 65(1), 263-293. 
Hasan, R. (2002). The impact of imported and domestic technologies on the productivity of firms: Panel data evidence from Indian manufacturing firms. Journal of Development Economics, 69(1), 23-49.

Hill, C. W. L., \& Snell, S. A. (1989). Effects of ownership structure and control on corporate productivity. Academy of Management Journal, 32(1), 25-46.

Huergo, E., \& Jaumandreu, J. (2004). Firms' age, process innovation and productivity growth. International Journal of Industrial Organization, 22(4), 541-559.

Ishengoma, E. K. (2004). Linking competitiveness to investment decisions: The case of manufacturing in Tanzania. African Finance Journal, 6, 56-89.

Kumar, N. (2002). Multinational enterprises in India: Industrial distribution. London: Routledge.

Kumar, N., \& Siddharthan, N. S. (1994). Technology, firm size and export behavior in developing countries: The case of Indian enterprises. Journal of Development Studies, 31(2), 289-309.

Lal, K. (2002). E-business and manufacturing sector: A study of small and medium-sized enterprises in India. Research Policy, 31(7), 11991211.

Lall, S. (2001). Competitiveness, technology and skills. Cheltenham: Edward Elgar Publishing.

Lall, S., \& Urata, S. (Eds.). (2003). Competitiveness, FDI and technological activity in East Asia. Cheltenham: Edward Elgar Publishing.

Lichtenberg, F. R., \& Siegel, D. (1991). The impact of R\&D investment on productivity: New evidence using linked R\&D-LRD data. Economic Inquiry, 29(2), 203-229.

Mahmood, T., Din, M., Ghani, E., \& Iqbal, M. M. (2009). An analysis of technology adoption by export-oriented manufacturers in Pakistan [with comments]. Pakistan Development Review, 48(4), 939-948. 
Mathews, J. A., \& Cho, D.-S. (2007). Tiger technology: The creation of a semiconductor industry in East Asia. Cambridge: Cambridge University Press.

Mayer, J. (2001). Technology diffusion, human capital and economic growth in developing countries (Discussion Paper No. 154). New York: UNCTAD.

Parhi, M. (2008, September). Technological dynamism of Indian automotive firms: A close look at the factors inducing learning and capability building. Paper presented at the VI Globelics Conference, Mexico City.

Porter, M. E. (1990). The competitive advantage of nations. Harvard Business Review, 68(2), 73-93.

Stoneman, P. (1986). Technological diffusion, the viewpoint of economic theory. Ricerche Economiche, 40, 585-606.

Stoneman, P., \& Kwon, M. J. (1996). Technology adoption and firm profitability. The Economic Journal, 106(437), 952-962.

Suri, T. (2011). Selection and comparative advantage in technology adoption. Econometrica, 79(1), 159-209. 